\title{
making empire respectable: the politics of race and sexual morality in 20th-century colonial cultures
}

\author{
ANN L. STOLER-University of Michigan
}

The shift away from viewing colonial elites as homogeneous communities of common interest marks an important trajectory in the anthropology of empire, signaling a major rethinking of gender relations within it. More recent attention to the internal tensions of colonial enterprises has placed new emphasis on the quotidian assertion of European dominance in the colonies, on imperial interventions in domestic life, and thus on the cultural prescriptions by which European women and men lived (Callan and Ardener 1984; Knibiehler and Goutalier 1985; Reijs, et. al 1986; Callaway 1987; Strobel 1987). Having focused on how colonizers have viewed the indigenous Other, we are beginning to sort out how Europeans in the colonies imagined themselves and constructed communities built on asymmetries of race, class and gender-entities significantly at odds with the European models on which they were drawn.

These feminist attempts to engage the gender politics of Dutch, French and British imperia! cultures converge on some strikingly similar observations; namely that European women in these colonies experienced the cleavages of racial dominance and internal social distinctions very differently than men precisely because of their ambiguous positions, as both subordinates in colonial hierarchies and as active agents of imperial culture in their own right. Concomitantly, the majority of European women who left for the colonies in the late 19th and early 20th centuries confronted profoundly rigid restrictions on their domestic, economic and political options, more limiting than those of metropolitan Europe at the time and sharply contrasting the opportunities open to colonial men.

In one form or another these studies raise a basic question: in what ways were gender inequalities essential to the structure of colonial racism and imperial authority? Was the strident misogyny of imperial thinkers and colonial agents a byproduct of received metropolitan values ("they just brought it with them"), a reaction to contemporary feminist demands in Europe ("women need to be put back in their breeding place"), or a novel and pragmatic response to the conditions of conquest? Was the assertion of European supremacy in terms of patriotic manhood and racial virility an expression of imperial domination or a defining feature of it?

With sustained challenges to European rule in African and Asian colonies in the early 20th century, sexual prescriptions by class, race and gender became increasingly central to the politics of rule and subject to new forms of scrutiny by colonial states. Focusing on the Netherlands Indies and French Indochina, but drawing on other contexts, this article examines how the very categories of "colonizer" and "colonized" were increasingly secured through forms of sexual control which defined the common political interests of European colonials and the cultural investments by which they identified themselves. The metropolitan and colonial discourses on health, "racial degeneracy," and social reform from this period reveal how sexual sanctions demarcated positions of power by enforcing middle-class conventions of respectability and thus the personal and public boundaries of race. [sexuality, race-thinking, hygiene, colonial cultures, Southeast Asia] 
In this paper I examine some of the ways in which colonial authority and racial distinctions were fundamentally structured in gendered terms. I look specifically at the administrative and medical discourse and management of European sexual activity, reproduction and marriage as it articulated with the racial politics of colonial rule. Focusing on French Indochina and the Dutch East Indies in the early 20th century, but drawing on other contexts, I suggest that the very categories of "colonizer" and "colonized" were secured through forms of sexual control which defined the domestic arrangements of Europeans and the cultural investments by which they identified themselves. ${ }^{1}$ Gender specific sexual sanctions demarcated positions of power by refashioning middle-class conventions of respectability, which, in turn, prescribed the personal and public boundaries of race.

Colonial authority was constructed on two powerful, but false, premises. The first was the notion that Europeans in the colonies made up an easily identifiable and discrete biological and social entity; a "natural" community of common class interests, racial attributes, political affinities and superior culture. The second was the related notion that the boundaries separating colonizer from colonized were thus self-evident and easily drawn (Stoler 1989). Neither premise reflected colonial realities (see for example, Cooper 1980; Drooglever 1980; Ridley 1983; Prochaska 1989; Comaroff (this volume)). Internal divisions developed out of conflicting economic and political agendas, frictions over appropriate methods for safeguarding European privilege and power, competing criteria for reproducing a colonial elite and for restricting its membership.

This latter, the colonial politics of exclusion, was contingent on constructing categories, legal and social classifications designating who was "white," who was "native," who could become a citizen rather than a subject, which children were legitimate progeny and which were not. What mattered were not only one's physical properties but who counted as "European" and by what measure. ${ }^{2}$ Skin shade was too ambiguous; bank accounts were mercurial; religious belief and education were crucial but never enough. Social and legal standing derived not only from color, but from the silences, acknowledgments, and denials of the social circumstances in which one's parents had sex (Martinez-Alier 1974; Ming 1983; Taylor 1983). Sexual unions in the context of concubinage, domestic service, prostitution or church marriage derived from the hierarchies of rule; but these were negotiated and contested arrangements, bearing on individual fates and the very structure of colonial society. Ultimately inclusion or exclusion required regulating the sexual, conjugal and domestic life of both Europeans in the colonies and their colonized subjects.

Colonial observers and participants in the imperial enterprise appear to have had unlimited interest in the sexual interface of the colonial encounter (Malleret 1934:216; Pujarniscle 1931:106; Loutfi 1970:36). Probably no subject is discussed more than sex in colonial literature and no subject more frequently invoked to foster the racist stereotypes of European society. The tropics provided a site of European pornographic fantasies long before conquest was underway, but with a sustained European presence in colonized territories, sexual prescriptions by class, race and gender became increasingly central to the politics of rule and subject to new forms of scrutiny by colonial states (Loutfi 1971; Gilman 1985:79). ${ }^{3}$

While anthropologists have attended to how European, and particularly Victorian, sexual more affected indigenous gendered patterns of economic activity, political participation and social knowledge, less attention has been paid to the ways in which sexual control affected the very nature of colonial relations themselves (Tiffany and Adams 1985). In colonial scholarship more generally, sexual domination has figured as a social metaphor of European supremacy. Thus, in Edward Said's treatment of orientalist discourse, the sexual submission and possession of Oriental women by European men "stands for the pattern of relative strength between East and West" (1979:6). In this "male power-fantasy," the Orient is penetrated, silenced and possessed (ibid:207). Sexuality illustrates the iconography of rule, not its pragmatics; sexual assymetries are tropes to depict other centers of power. 
Such a treatment begs some basic questions. Was sexuality merely a graphic substantiation of who was, so to speak, on the top? Was the medium the message, or did sexual relations always "mean" something else, stand in for other relations, evoke the sense of other (pecuniary, political, or some possibly more subliminal) desires? This analytic slippage between the sexual symbols of power and the politics of sex runs throughout the colonial record and contemporary commentaries upon it. Certainly some of this is due to the polyvalent quality of sexuality; symbolically rich and socially salient at the same time. But sexual control was more than a "social enactment"- much less a convenient metaphor-for colonial domination (Jordan 1968:141); it was, as $I$ argue here, a fundamental class and racial marker implicated in a wider set of relations of power (Ballhatchet 1980).

The relationship between gender prescriptions and racial boundaries still remains unevenly unexplored. While we know that European women of different classes experienced the colonial venture very differently from one another and from men, we still know relatively little about the distinct investments they had in a racism they shared (Van Helten and Williams 1983; Knibielher and Goutalier 1985; Callaway 1987). New feminist scholarship has begun to sort out the unique colonial experience of European women as they were incorporated into, resisted and affected the politics of their men. But the emphasis has tended to be on the broader issue of gender subordination and colonial authority, not more specifically on how sexual control figured in the construction of racial boundaries per se. ${ }^{4}$

The linkage between sexual control and racial tensions is both obvious and elusive at the same time. While sexual fear may at base be a racial anxiety, we are still left to understand why it is through sexuality that such anxieties are expressed (Takaki 1977). If, as Sander Gilman (1985) claims, sexuality is the most salient marker of Otherness, organically representing racial difference, then we should not be surprised that colonial agents and colonized subjects expressed their contests-and vulnerabilities-in these terms (see Chatterjee this volume).

An overlapping set of discourses has provided the psychological and economic underpinnings for colonial distinctions of difference, linking fears of sexual contamination, physical danger, climatic incompatability, and moral breakdown to a European colonial identity with a racist and class-specific core. Colonial scientific reports and the popular press are laced with statements and queries varying on a common theme: "native women bear contagions"; "white women become sterile in the tropics"; "colonial men are susceptible to physical, mental and moral degeneration when they remain in their colonial posts too long." To what degree are these statements medically or politically grounded? We need to unpack what is metaphor, what is perceived as dangerous (is it disease, culture, climate, or sex?) and what is not.

In the sections that follow I look at the relationship between the domestic arrangements of colonial communities and their wider political structures. Part l examines the colonial debates over European family formation, over the relationship between subversion and sex in an effort to trace how evaluations of concubinage, morality and white prestige more generally were altered by new tensions within colonial cultures and by new challenges to imperial rule.

Part Il examines what I call the "cultural hygiene" of colonialism. Focusing on the early 20th century as a break point, I take up the convergent metropolitan and colonial discourses on health hazards in the tropics, race-thinking and social reform as they related to shifts in the rationalization of colonial management. In tracing how fears of "racial degeneracy" were grounded in class-specific sexual norms, I return to how and why biological and cultural distinctions were defined in gender terms.

\section{the domestic politics of colonialism: concubinage and the restricted entry of European women}

The regulation of sexual relations was central to the development of particular kinds of colonial settlements and to the allocation of economic activity within them. Who bedded and 
wedded with whom in the colonies of France, England, Holland and Iberia was never left to chance. Unions between Annamite women and French men, between Javanese women and Dutch men, between Spanish men and Inca women produced offspring with claims to privilege, whose rights and status had to be determined and prescribed. From the early $1600 \mathrm{~s}$ through the 20th century the sexual sanctions and conjugal prohibitions of colonial agents were rigorously debated and carefully codified. In these debates over matrimony and morality, trading and plantation company officials, missionaries, investment bankers, military high commands and agents of the colonial state confronted one another's visions of empire, and the settlement patterns on which it would rest.

In 1622 the Dutch East Indies Company (VOC) arranged for the transport of six poor but marriageable young Dutch women to Java, providing them with clothing, a dowry upon marriage and a contract binding them to five years in the Indies (Taylor 1983:12). Aside from this and one other short-lived experiment, immigration of European women to the East Indies was consciously restricted for the next 200 years. Enforcing the restriction by selecting bachelors as their European recruits, the VOC legally and financially made concubinage the most attractive domestic option for its employees (Blussé 1986:173; Ming 1983:69; Taylor 1983:16).

It was not only the VOC which had profited from such arrangements. In the 19th and early 20th centuries, salaries of European recruits to the colonial armies, bureaucracies, plantation companies and trading enterprises were kept artifically low because local women provided domestic services for which new European recruits would otherwise have had to pay. In the mid-1800s, such arrangements were de rigueur for young civil servants intent on setting up households on their own (Ritter 1856:21). Despite some clerical opposition, at the end of the century concubinage was the most prevalent living arrangement for European colonials in the Indies (Ming 1983:70; Taylor 1983:16; van Marle 1952:486).

Referred to as nyai in Java and Sumatra, congai in Indochina, and petite épouse throughout the French empire, the colonized woman living as a concubine to a European man formed the dominant domestic arrangement in colonial cultures through the early 20th century. Unlike prostitution, which could and often did result in a population of syphilitic and therefore nonproductive European men, concubinage was considered to have a stabilizing effect on political order and colonial health-a relationship that kept men in their barracks and bungalows, out of brothels and less inclined to perverse liaisons with one another.

In Asia and Africa corporate and government decision makers invoked the social services which local women supplied as "useful guides to the language and other mysteries of the local societies" (Malleret 1934:216; Cohen 1971:122). Handbooks for incoming plantation employees bound for Tonkin, Sumatra and Malaya urged men to find local "companions" as a prerequisite for quick acclimatization, as insulation from the ill-health that sexual abstention, isolation and boredom were thought to bring (Butcher 1979:200, 202; Hesselink 1987:208; Braconier 1933:922; Dixon 1913:77). Although British and Dutch colonial governments officially banned concubinage in the early 20 th century, such measures were only selectively enforced. It remained tacitly condoned and practiced long after (Hyam 1986; Callaway 1987:49). In Sumatra's plantation belt newly opened in the late 19th century, for example, Javanese and Japanese huishoudsters (householders) remained the rule rather than the exception through the 1920s (Clerkx 1961:87-93; Stoler 1985a:31-34; Lucas 1986:84).

Concubinage was a contemporary term which referred to the cohabitation outside of marriage between European men and Asian women; in fact, it glossed a wide range of arrangements which included sexual access to a non-European woman as well as demands on her labor and legal rights to the children she bore (Pollman 1986:100; Lucas 1986:86). ${ }^{5}$ Native women (like European women in a later period) were to keep men physically and psychologically fit for work, marginally content, not distracting or urging them out of line, imposing neither the time consuming nor financial responsibilities that European family life was thought to demand (Chivas-Baron 1929:103). ${ }^{\circ}$ 
To say that concubinage reinforced the hierarchies on which colonial societies were based is not to say that it did not make those distinctions more problematic at the same time. Grossly uneven sex ratios on North Sumatran estates made for intense competition among male workers and their European supervisors, with vrouwen perkara (disputes over women) resulting in assaults on whites, new labor tensions and dangerous incursions into the standards deemed essential for white prestige (Stoler 1985a:33; Lucas 1986:90-91). In the Netherlands Indies more generally an unaccounted number of impoverished Indo-European women moving between prostitution and concubinage further disturbed the racial sensibilities of the Dutch-born elite (Hesselink 1987:216). Metropolitan critics were particularly disdainful of such domestic arrangements on moral grounds-all the more so when these unions were sustained and personally significant relationships, thereby contradicting the racial premise of concubinage as an emotionally unfettered convenience.? But perhaps most important, the tension between concubinage as a confirmation and compromise of racial hierarchy was realized in the progeny that it produced, "mixed-bloods," poor "indos," and abandoned "métis" children who straddled the divisions of ruler and ruled threatened to blur the colonial divide.

Nevertheless, colonial governments and private business tolerated concubinage and actively encouraged it-principally by restricting the emigration of European women to the colonies and by refusing employment to married male European recruits. Although many accounts suggest that European women chose to avoid early pioneering ventures, and this must have been true in some cases, the choice was more often not their own (cf. Fredrickson 1981:109). Nor were the restrictions on marriage and women's emigration lifted as each colony became politically stable, medically upgraded and economically secure, as it is often claimed. Conjugal constraints lasted well into the 20th century, long after rough living and a scarcity of amenities had become conditions of the past. In the Indies army, marriage was a privilege of the officer corps while barrack concubinage was instituted and regulated for the rank and file. In the 20th century, formal and informal prohibitions set by banks, estates and government services operating in Africa, India, and Southeast Asia, restricted marriage during the first three to five years of service, while some prohibited it altogether (Moore-Gilbert 1986:48; Woodcock 1969:164; Tirefort 1979:134; Gann and Duignan 1978:240).

European demographics in the colonies were shaped by these economic and political exigencies and thus were sharply skewed by sex. Among the laboring immigrant and native populations as well as among Europeans, the number of men exceeded that of women by 2 to 25 times. While in the Netherlands Indies, the overall ratio of European women to men rose from 47:100 to $88: 100$ between 1900 and 1930, on Sumatra's plantation belt in 1920 there were still only 61 European women per 100 European men (Taylor 1983:128; Koloniale Verslag quoted in Lucas 1986:82). In Tonkin, European men (totaling more than 14,000) sharply outnumbered European women (just over 3000) as late as 1931 (Gantes 1981:138). What is important here is that by controlling the availability of European women and the sorts of sexual access condoned, state and corporate authorities controlled the very social geography of the colonies, fixing the conditions under which European populations and privileges could be reproduced.

The marriage prohibition was both a political and economic issue, defining the social contours of colonial communities and the standards of living within them. But, as significantly, it revealed how deeply the conduct of private life, and the sexual proclivities which individuals expressed were tied to corporate profits and to the security of the colonial state. Nowhere were the incursions on domestic life more openly contested than in North Sumatra in the early 1900 s. Unseemly domestic arrangements were thought to encourage subversion as strongly as acceptable unions could avert it. Family stability and sexual "normalcy" were thus linked to political agitation or quiescence in very concrete ways.

Since the late 19th century, the major North Sumatran tobacco and rubber companies had neither accepted married applicants nor allowed them to take wives while in service (Schoevers 
1913:38; Clerkx 1961:31-34). Company authorities argued that new employees with families in tow would be a financial burden, risking the emergence of a "European proletariat" and thus a major threat to white prestige (Kroniek 1917:50; Sumatra Post 1913). Low-ranking plantation employees protested against these company marriage restrictions, an issue which mobilized their ranks behind a broad set of demands (Stoler 1989:144). Under employee pressure, the prohibition was relaxed to a marriage ban for the first five years of service. This restriction, however, was never placed on everyone; it was pegged to salaries and dependent on the services of local women which kept the living costs and wages of subordinate and incoming staff artifically low.

Domestic arrangements thus varied as government officials and private businesses weighed the economic versus political costs of one arrangement over another, but such calculations were invariably meshed. Europeans in high office saw white prestige and profits as inextricably linked and attitudes toward concubinage reflected that concern (Brownfoot 1984:191). Thus in Malaya through the 1920s, concubinage was tolerated precisely because "poor whites" were not. Government and estate administrators argued that white prestige would be imperiled if European men became impoverished in attempting to maintain middle-class lifestyles and European wives (Butcher 1979:26). In late 19th century Java, in contrast, concubinage itself was considered to be a major source of white pauperism; in the early 1900 s it was vigorously condemned at precisely the same time that a new colonial morality passively condoned illegal brothels (Het Pauperisme Commissie 1901; Nieuwenhuys 1959:20-23; Hesselink 1987:208).

What explains such a difference? At least part of the answer must be sought in the effects concubinage was seen to have on European cultural identity and on the concerns for the community consensus on which it rests. Concubinage "worked" as long as the supremacy of Homo Europeaus was clear. When it was thought to be in jeopardy, vulnerable, or less than convincing, as in the 1920s in Sumatra, colonial elites responded by clarifying the cultural criteria of privilege and the moral premises of their unity. Concubinage was replaced by more restricted sexual access in the politically safe (but medically unsatisfactory) context of prostitution, and, where possible, in the more desirable setting of marriage between "full-blooded" Europeans (Taylor 1977:29). As we shall see in other colonial contexts, such shifts in policy and practice often coincided with an affirmation of social hierarchies and racial divisions in less ambiguous terms. ${ }^{8}$ Thus, it was not only morality which vacillated but the very definition of white prestige- and what its defense should entail. What upheld that prestige was not a constant; concubinage was socially lauded at one time and seen as a political menace at another. Appeals to white prestige were a gloss for different intensities of racist practice, gender-specific and culturally coded.

Thus far I have treated colonial communities as a generic category despite the sharp demographic, social and political distinctions among them. North Sumatra's European-oriented, overwhelmingly male colonial population, for example, contrasted sharply with the more sexually balanced mestizo culture which emerged in 17 th- and 18 th-century colonial Java. ${ }^{9}$ Such demographic variation, however, was not the "bedrock" of social relations (Jordan 1968:141); sex ratios derived from specific strategies of social engineering, and were thus political responses in themselves. While recognizing that these demographic differences and the social configurations to which they gave rise still need to be explained, I have chosen here to trace some of the common politically gendered issues which a range of colonial societies shared; that is, some of the similar-and counter-intuitive-ways in which the positioning of European women facilitated racial distinctions and new efforts to modernize colonial control. ${ }^{10}$

racist but moral women: innocent but immoral men

Perhaps nothing is as striking in the sociological accounts of colonial communities as the extraordinary changes which are said to accompany the entry of European-born women. These 
adjustments shifted in one direction; toward European lifestyles accentuating the refinements of privilege and the etiquettes of racial difference. Most accounts agree that the presence of these women put new demands on the white communities to tighten their ranks, clarify their boundaries, and mark out their social space. The material culture of French settlements in Saigon, outposts in New Guinea, and estate complexes in Sumatra were retailored to accommodate the physical and moral requirements of a middle-class and respectable feminine contingent (Malleret 1934; Gordon and Meggitt 1985; Stoler 1989). Housing structures in Indochina were partitioned, residential compounds in the Solomon Islands enclosed, servant relations in Hawaii formalized, dress codes in Java altered, food and social taboos in Rhodesia and the Ivory Coast became more strict. Taken together, the changes encouraged new kinds of consumption and new social services catering to these new demands (Boutilier 1982; Spear 1963; Woodcock 1969; Cohen 1971).

The arrival of large numbers of European women thus coincided with an embourgeoisment of colonial communities and with a significant sharpening of racial lines. European women supposedly required more metropolitan amenities than men and more spacious surroundings to allow it; their more delicate sensibilities required more servants and thus suitable quartersdiscrete and enclosed. In short, white women needed to be maintained at elevated standards of living, in insulated social spaces cushioned with the cultural artifacts of "being European." Whether women or men set these new standards is left unclear. Who exhibited "overconcern" and a "need for" segregation (Beidelman 1982:13)? Male doctors advised French women in Indochina to have their homes built with separate domestic and kitchen quarters (Grall 1908:74). Segregrationist standards were what women "deserved," and more importantly what white male prestige required that they maintain.

Colonial rhetoric on white women was riddled with contradictions. At the same time that new female immigrants were chided for not respecting the racial distance of local convention, an equal number of colonial observers accused these women of being more avid racists in their own right (Spear 1963; Nora 1961). Allegedly insecure and jealous of the sexual liaisons of European men with native women, bound to their provincial visions and cultural norms, European women in Algeria, the Indies, Madagscar, India, and West Africa were uniformly charged with constructing the major cleavages on which colonial stratification rested (Spear 1963:140; Nora 1961:174; Mannoni 1964[1950]:115; Gan and Duignan 1978:242; Kennedy 1947:164; Nandy 1983:9).

What is most startling here is that women, otherwise marginal actors on the colonial stage, are charged with dramatically reshaping the face of colonial society, imposing their racial will on African and Asian colonies where "an iron curtain of ignorance" replaced "relatively unrestrained social intermingling" in earlier years (Vere Allen 1970:169; Cohen 1971:122). European women were not only the bearers of racist beliefs, but hardline operatives who put them into practice, encouraging class distinctions among whites while fostering new racial antagonisms, no longer muted by sexual access (Vere Allen 1970:168). ${ }^{11}$ Are we to believe that sexual intimacy with European men yielded social mobility and political rights for colonized women? Or, even less likely, that because British civil servants bedded with Indian women, somehow Indian men had more "in common" with British men and enjoyed more parity? Colonized women could sometimes parlay their positions into personal profit and small rewards, but these were individual negotiations with no social, legal, or cumulative claims.

Male colonizers positioned European women as the bearers of a redefined colonial morality. But to suggest that women fashioned this racism out of whole cloth is to miss the political chronology in which new intensities of racist practice arose. In the African and Asian contexts already mentioned, the arrival of large numbers of European wives, and particularly the fear for their protection, followed from new terms and tensions in the colonial encounter. The presence and protection of European women was repeatedly invoked to clarify racial lines. It coincided with perceived threats to European prestige (Brownfoot 1984:191), increased racial conflict 
(Strobel 1987:378), covert challenges to the colonial order, outright expressions of nationalist resistance, and internal dissension among whites themselves (Stoler 1989:147).

If white women were the primary force behind the decline of concubinage as is often claimed, they did so as participants in a broader racial realignment and political plan (Knibiehler and Goutalier 1985:76). This is not to suggest that European women were passive in this process, as the dominant themes in their novels attest (Taylor 1977:27). Many European women did oppose concubinage not because of their inherent jealousy of native women, but, as they argued, because of the double standard it condoned for European men (Clerkx 1961; Lucas 1986:94-95). ${ }^{12}$ The voices of European women, however, had little resonance until their objections coincided with a realignment in racial and class politics.

\section{dealing with transgressions: policing the peril}

The gender-specific requirements for colonial living, referred to above, were constructed on heavily racist evaluations which pivoted on the heightened sexuality of colonized men (Tiffany and Adams 1985). Although European women were absent from men's sexual reveries in colonial literature, men of color were considered to see them as desired and seductive figures. European women needed protection because men of color had "primitive" sexual urges and uncontrollable lust, aroused by the sight of white women (Strobel 1987:379; Schmidt 1987:411). In some colonies, that sexual threat was latent; in others it was given a specific name.

In southern Rhodesia and Kenya in the 1920s and 1930s, preoccupations with the "Black Peril" (referring to the professed dangers of sexual assault on white women by black men) gave rise to the creation of citizens' militias, ladies' riflery clubs and investigations as to whether African female domestic servants would not be safer to employ than men (Kirkwood 1984:158; Schmidt 1987:412; Kennedy 1987:128-147). In New Guinea the White Women's Protection Ordinance of 1926 provided "the death penalty for any person convicted for the crime of rape or attempted rape upon a European woman or girl" (Inglis 1975:vi). And as late as 1934, Solomon Islands authorities introduced public flogging as punishment for "criminal assaults on [white] females" (Boutilier 1984:197).

What do these cases have in common? The rhetoric of sexual assault and the measures used to prevent it had virtually no correlation with the incidence of rape of European women by men of color. Just the contrary: there was often no evidence, ex post facto or at the time, that rapes were committed or that rape attempts were made (Schmidt 1987; Inglis 1975; Kirkwood 1984; Kennedy 1987; Boutilier 1984). This is not to suggest that sexual assaults never occurred, but that their incidence had little to do with the fluctuations in anxiety about them. Secondly, the rape laws were race-specific; sexual abuse of black women was not classified as rape and therefore was not legally actionable, nor did rapes committed by white men lead to prosecution (Mason 1958:246-247). If these accusations of sexual threat were not prompted by the fact of rape, what did they signal and to what were they tied?

Allusions to political and sexual subversion of the colonial system went hand in hand. Concern over protection of white women intensified during real and perceived crises of controlprovoked by threats to the internal cohesion of the European communities or by infringements on their borders. While the chronologies differ, we can identify a patterned sequence of events in which Papuan, Algerian, and South African men heightened their demands for civil rights and refused the constraints imposed upon their education, movements, or dress (Inglis 1975:8,11; Sivan 1983:178). Rape charges were thus based on perceived transgressions of political and social space. "Attempted rapes" turned out to be "incidents" of a Papuan man "discovered" in the vicinity of a white residence, a Fijian man who entered a European patient's room, a male servant poised at the bedroom door of a European woman asleep or in half-dress 
(Boutilier 1984:197; Inglis 1975:11; Schmidt 1987:413). With such a broad definition of danger, all colonized men of color were potential aggressors.

Accusations of sexual assault frequently followed upon heightened tensions within European communities-and renewed efforts to find consensus within them. In South Africa and Rhodesia, the relationship between reports of sexual assault and strikes among white miners and railway workers is well documented (van Onselen 1982:51; Kennedy 1987:138). Similarly, in the late 1920s when labor protests by Indonesian workers and European employees were most intense, Sumatra's corporate elite expanded their vigilante organizations, intelligence networks and demands for police protection to ensure their women were safe and their workers "in hand" (Stoler 1985b). In this particular context where the European community had been blatantly divided between low-ranking estate employees and the company elite, common interests were emphasized and domestic situations were rearranged.

In Sumatra's plantation belt, subsidized sponsorship of married couples replaced the recruitment of single Indonesian workers and European staff, with new incentives provided for family formation in both groups. This recomposed labor force of family men in "stable households" explicitly weeded out the politically malcontent. With the marriage restriction finally lifted for European staff in the 1920s, young men sought marriages with Dutch women. Higher salaries, upgraded housing, elevated bonuses, and a more mediated chain of command between colonized fieldworker and colonial managers clarified economic and political interests. With this shift, the vocal opposition to corporate and government directives, sustained by an independent union of European subordinates for nearly two decades, was effectively dissolved (Stoler 1989:152-153).

The remedies intended to alleviate sexual danger embraced a common set of prescriptions for securing white control: increased surveillance of native men, new laws stipulating severe corporal punishment for the transgression of sexual and social boundaries, and the creation of areas made racially off limits. This moral rearmament of the European community and reassertion of its cultural identity charged European women with guarding new norms. While instrumental in promoting while solidarity, it was partly at their own expense. As we shall see, they were nearly as closely surveilled as colonized men (Strobel 1987).

While native men were legally punished for alleged sexual assaults, European women were frequently blamed for provoking those desires. New arrivals from Europe were accused of being too familiar with their servants, lax in their commands, indecorous in speech and dress (Vellut 1982:100; Kennedy 1987:141; Schmidt 1987:413). The Rhodesian immorality act of 1916 "made it an offence for a white woman to make an indecent suggestion to a male native" (Mason 1958:247). In Papua New Guinea "everyone" in the Australian community agreed that rape assaults were caused by a "younger generation of white women" who simply did not know how to treat servants (Inglis 1975:80). In Rhodesia as in Uganda, women were restricted to activities within the European enclaves and dissuaded from taking up farming on their own (Gartrell 1984:169; Kennedy 1987:141). As in the American South, "etiquettes of chivalry controlled white women's behavior even as lit] guarded caste lines" (Dowd Hall 1984:64). A defense of community, morality and white male power affirmed the vulnerability of white women and the sexual threat posed by native men, and created new sanctions to limit the liberties of both.

Although European colonial communities in the early 20th century assiduously monitored the movements of European women, some European women did work. French women in the settler communities of Algeria and Senegal ran farms, rooming houses, and shops along with their men (Baroli 1967:159; O'Brien 1972). Elsewhere, married European women "supplemented" their husbands' incomes, helping to maintain the "white standard" (Tirefort 1979; Mercier 1965:292). Women were posted throughout the colonial empires as missionaries, nurses, and teachers; while some women openly questioned the sexist policies of their male 
superiors, by and large their tasks buttressed rather than contested the established cultural order (Knibiehler and Goutalier 1985; Callaway 1987:111).

French feminists urged women with skills (and a desire for marriage) to settle in Indochina at the turn of the century, but colonial administrators were adamantly against their immigration. Not only was there a surfeit of widows without resources, but European seamstresses, florists and children's outfitters could not compete with the cheap and skilled labor provided by well established Chinese firms (Corneau 1900:10,12). In Tonkin in the 1930s there was still "Iittle room for single women, be they unmarried, widowed or divorced"; most were shipped out of the colony at the government's charge (Gantes 1981:45). ${ }^{13}$ Firmly rejecting expansion based on "poor white" (petit blanc) settlement as in Algeria, French officials in Indochina dissuaded colons with insufficient capital from entry and promptly repatriated those who tried to remain. ${ }^{14}$ Single women were seen as the quintessential petit blanc, with limited resources and shopkeeper aspirations. Moreover, they presented the dangerous possibility that straitened circumstances would lead them to prostitution, thereby degrading European prestige at large.

In the Dutch East Indies, state officials identified European widows as one of the most economically vulnerable and impoverished segments of the European community (Het Pauperisme onder de Europeanen 1901 :28). Professional competence did not leave European women immune from marginalization. Single professional women were held in contempt as were European prostitutes, with surprisingly similar objections. ${ }^{15}$ The important point is that numerous categories of women fell outside the social space to which European colonial women were assigned; namely, as custodians of family welfare and respectability, and as dedicated and willing subordinates to, and supporters of, colonial men. The rigor with which these norms were applied becomes more comprehensible when we see how a European family life and bourgeois respectability became increasingly tied to notions of racial survival, imperial patriotism and the political strategies of the colonial state.

\section{white degeneracy, motherhood and the eugenics of empire}

de-gen-er-ate (adj.) [L. degeneratus, pp. of degenerare, to become unlike one's race, degenerate $<$ degener, not genuine, base < de-, from + genus, race, kind: see genus]. 1. having sunk below a former or normal condition, character, etc.; deteriorated. 2 . morally corrupt; depraved- $n$. a degenerate person, esp. one who is morally depraved or sexually perverted- $v i$-at'ed, -at'ing 1 . to decline or become debased morally, culturally, etc. 3. Biol. to undergo degeneration; deteriorate

[Webster's New World Dictionary 1972:371].

European women were essential to the colonial enterprise and the solidification of racial boundaries in ways that repeatedly tied their supportive and subordinate posture to community cohesion and colonial peace. These features of their positioning within imperial politics were powerfully reinforced at the turn of the century by a metropolitan bourgeois discourse (and an eminently anthropological one) intensely concerned with notions of "degeneracy" (Le Bras 1981:77). Middle-class morality, manliness and motherhood were seen as endangered by the intimately linked fears of "degeneration" and miscegenation in scientifically construed racist beliefs (Mosse 1978:82). ${ }^{16}$ Due to environmental and/or inherited factors, degeneracy could be averted positively by eugenic selection, or negatively by eliminating the "unfit" (Mosse 1978:87; Kevles 1985:70-84). Eugenic arguments used to explain the social malaise of industrialization, immigration and urbanization in the early 20 th century derived from the notion that acquired characteristics were inheritable and thus that poverty, vagrancy and promiscuity were class-linked biological traits, tied to genetic material as directly as nightblindness and blonde hair.

Appealing to a broad political and scientific constituency at the turn of the century, eugenic societies included advocates of infant welfare programs, liberal intellectuals, conservative businessmen, Fabians, and physicians with social concerns. By the 1920s, however, it contained an increasingly vocal number of those who called for and put into law, if not practice, the 
sterilization of significant numbers in the British, German and American working-class populations (Mosse 1978:87; 1982:122). ${ }^{17}$ Negative eugenics never gained the same currency in Holland as it did elsewhere, nevertheless, it seems clear from the Dutch and Dutch Indies scientific and popular press that concerns with hereditary endowment and with "Indo degeneracy" were grounded in a cultural racism that rivaled its French variant, if in a somewhat more muted form. ${ }^{\text {is }}$

Feminists attempted to appropriate this rhetoric for their own birth control programs, but eugenics was essentially elitist, racist and misogynist in principle and practice (Gordon 1976:395; Davin 1978; Hammerton 1979). Its proponents advocated a pronatalist policy toward the white middle and upper classes, a rejection of work roles for women that might compete with motherhood, and "an assumption that reproduction was not just a function but the purpose ... of a woman's life" (Gordon 1976:134). In France, England, Germany, and the United States, positive eugenics placed European women of "good stock" as "the fountainhead of racial strength" (Ridley 1983:91), exalting the cult of motherhood while subjecting it to more thorough scientific scrutiny (Davin 1978:12).

As part of metropolitan class politics, eugenics reverberated in the colonies in predictable as well as unexpected forms. The moral, biological and sexual referents of the notion of degeneracy (distinct in the dictionary citation above) came together in how the concept was actually deployed. The "colonial branch" of eugenics embraced a theory and practice concerned with the vulnerabilities of white rule and new measures to safeguard European superiority. Designed to control the procreation of the "unfit" lower orders, eugenics targeted "the poor, the colonized, or unpopular strangers" (Hobsbawm 1987:253). It was, however, also used by metropolitan observers against colonials, and by colonial elites against "degenerate" members among themselves (Koks 1931:179-189). While studies in Europe and the U.S. focused on the inherent propensity of the poor for criminality, in the Indies delinquency among "European" children was biologically linked to the amount of "native blood" among children of poor IndoEuropeans (Braconier 1918:11). Eugenics provided not so much a new vocabulary as it did a medical and moral basis for anxiety over white prestige which reopened debates over segregated residence and education, new standards of morality, sexual vigilance and the rights of certain Europeans to rule.

Eugenic influence manifested itself, not in the direct importation of metropolitan practices such as sterilization, but in a translation of the political principles and the social values which eugenics implied. In defining what was unacceptable, eugenics also identified what constituted a "valuable life": "a gender-specific work and productivity, described in social, medical and psychiatric terms" (Bock 1984:274). Applied to Europe colonials, eugenic statements pronounced what kind of people should represent Dutch or French rule, how they should bring up their children and with whom they should socialize. Those concerned with issues of racial survival and racial purity invoked moral arguments about the national duty of French, Dutch, British, and Belgian colonial women to stay at home.

If in Britain racial deterioration was conceived to be a result of the moral turpitude and the ignorance of working-class mothers, in the colonies, the dangers were more pervasive, the possibilities of contamination worse. Formulations to secure European rule pushed in two directions: on the one hand, away from ambiguous racial genres and open domestic arrangements, and on the other hand, toward an upgrading, homogenization, and a clearer delineation of European standards; away from miscegenation toward white endogamy, away from concubinage toward family formation and legal marriage; away from, as in the case of the Indies, mestizo customs and toward metropolitan norms (Taylor 1983; van Doorn 1985). As stated in the bulletin of the Netherlands Indies' Eugenic Society, "eugenics is nothing other than belief in the possibility of preventing degenerative symptoms in the body of our beloved moedervolken, or in cases where they may already be present, of counteracting them" (Rodenwaldt 1928:1). 
Like the modernization of colonialism itself, with its scientific management and educated technocrats with limited local knowledge, colonial communities of the early 20 th century were rethinking the ways in which their authority should be expressed. This rethinking took the form of asserting a distinct colonial morality, explicit in its reorientation toward the racial and class markers of "Europeanness," emphasizing transnational racial commonalities despite national differences-distilling a homo europeaus of superior health, wealth and intelligence as a white man's norm. As one celebrated commentator on France's colonial venture wrote: "one might be surprised that my pen always returns to the words blanc [white] or "European" and never to "Français" ... in effect colonial solidarity and the obligations that it entails allies all the peoples of the white races" (Pujarniscle 1931:72; also see Delavignette 1946:41).

Such sensibilities colored imperial policy in nearly all domains with fears of physical contamination merging with those of political vulnerability. To guard their ranks, whites had to increase their numbers and to ensure that their members neither blurred the biological nor political boundaries on which their power rested. ${ }^{19}$ In the metropole the socially and physically "unfit," the poor, the indigent and the insane were either to be sterilized or prevented from marriage. In the British and Belgian colonies, among others, it was these very groups among Europeans who were either excluded from entry or institutionalized while they were there and when possible were sent home (Arnold 1979; see also Vellut 1987:97).

Thus, whites in the colonies adhered to a politics of exclusion that policed their members as well as the colonized. Such concerns were not new to the 1920s (Taylor 1983; Sutherland 1982). As early as the mid-18th century, the Dutch East Indies Company had already taken "draconian measures" to control pauperism among "Dutchmen of mixed blood" (Encyclopedie van Nederland-Indie 1919:367). In the same period, the British East Indies Company legally and administratively dissuaded lower-class European migration and settlement, with the argument that it might destroy Indian respect for "the superiority of the European character" (quoted in Arnold 1983:139). Patriotic calls to populate Java in the mid-1800s with poor Dutch farmers were also condemned, but it was with new urgency that these possibilities were rejected in the following century as challenges to European rule were more profoundly felt.

Measures were taken both to avoid poor white migration and to produce a colonial profile that highlighted the vitality, colonial patriotism, and racial superiority of European men (Loutfi 1971:112-113; Ridley 1983:104). ${ }^{20}$ Thus, British colonial administrators were retired by the age of 55, ensuring that "no Oriental was ever allowed to see a Westerner as he aged and degenerated, just as no Westerner needed ever to see himself . . . as anything but a vigorous, rational, ever-alert young Raj" (Said 1978:42). In the 20th century, these "men of class" and "men of character" embodied a modernized and renovated colonial rule; they were to safeguard the colonies against physical weakness, moral decay and the inevitable degeneration that long residence in the colonies encouraged and the temptations that interracial domestic situations had allowed.

Given this ideal, it is not surprising that colonial communities strongly discouraged the presence of nonproductive men. Dutch and French colonial administrators expressed a constant concern with the dangers of unemployed or impoverished Europeans. During the succession of economic crises in the early 20th century, relief agencies in Sumatra, for example, organized fund raisers, hill station retreats and small-scale agricultural schemes to keep "unfit" Europeans "from roaming around" (Kroniek 1917:49). The colonies were neither open for retirement nor tolerant of the public presence of poor whites. During the 1930s depression when tens of thousands of Europeans in the Indies found themselves without jobs, government and private resources were quickly mobilized to ensure that they were not "reduced" to native living standards (Veerde 1931; Kantoor van Arbeid 1935). Subsidized health care, housing and education complemented a rigorous affirmation of European cultural standards in which European womanhood played a central role in keeping men civilisé. 


\section{on cultural hygiene: the dynamics of degeneration}

The shift in imperial thinking that we can identify in the early 20 th century focuses not only on the Otherness of the colonized, but on the Otherness of colonials themselves. In metropolitan France a profusion of medical and sociological tracts pinpointed the colonial as a distinct and degenerate social type, with specific psychological and even physical characteristics (Maunier 1932; Pujarniscle 1931)." Some of that difference was attributed to the debilitating results of climate and social milieu, "such that after a certain time, he [the colonial] has become both physically and morally a completely different man" (Maunier 1932:169).

Medical manuals warned that people who stayed "too long" were in grave danger of overfatigue, of individual and racial degeneration, of physical breakdown (not just illness), of cultural contamination and neglect of the conventions of supremacy, and agreement about what they were (Dupuy 1955:184-185). What were identified as the degraded and unique characteristics of French colonials- "ostentation," "speculation," "inaction," and a general "demoralisation" - where "faults" contracted from native culture, which now marked them as décivilisé (Maunier 1932:174; laurequiberry 1924:25).

Colonial medicine reflected and affirmed this slippage between physical, moral and cultural degeneracy in numerous ways. The climatic, social and work conditions of colonial life gave rise to a specific set of psychotic disorders affecting l'equilibre cerebral, predisposing Europeans in the tropics to mental breakdown (Hartenberg 1910; Abatucci 1910). Neurasthenia was a major problem in the French empire and supposedly accounted for more than half the Dutch repatriations from the Indies to Holland (Winckel 1938:352). In Europe and America, it was "the phantom disease ... the classic illness of the late 19th century," intimately linked to sexual deviation and to the destruction of the social order itself (Gilman 1985:199,202).

While in Europe neurasthenia was considered to signal a decadent overload of "modern civilization" and its high-pitched pace, in the colonies its etiology took the reverse form. CoIonial neurasthenia was allegedly caused by a distance from civilization and European community, and by proximity to the colonized. The susceptibility of a colonial male was increased by an existence "outside of the social framework to which he was adapted in France, isolation in outposts, physical and moral fatigue, and modified food regimes" (Joyeux 1937:335). ${ }^{22}$

The proliferation of hill stations in the 20th century reflected these political and physical concerns. Invented in the early 19 th century as sites for military posts and sanatoria, hill stations provided "European-like environments" in which colonials could recoup their physical and mental well-being by simulating the conditions "at home" (King 1976:165). Isolated at relatively high altitudes, they took on new importance with increasing numbers of European women and children, considered particularly susceptible to anemia, depression and illhealth. ${ }^{23}$ Vacation bungalows and schools built in these "naturally" segregated surroundings provided cultural refuge and regeneration (Price 1939).

Some doctors considered the only treatment to be "le retour en Europe" (Joyeux 1937:335; Pujarniscle 1931:28). Others encouraged a local set of remedies, prescribing a bourgeois ethic of morality and work. This included sexual moderation, a "regularity and regimentation" of work, abstemious diet, physical exercise and European comradery, buttressed by a solid family life with European children, raised and nurtured by a European wife (Grall 1908:51; Price 1939: also see Kennedy 1987:123). Guides to colonial living in the 1920s and 1930s reveal this marked shift in outlook; Dutch, French and British doctors now denounced the unhealthy, indolent life styles of "old colonials," extolling the active, engaged and ever-busy activities of the new breed of colonial husband and wife (Raptchinsky 1941:46). Women were exhorted to actively participate in household management and childcare, and otherwise to divert themselves with botanical collections and "good works" (Chivas-Baron 1929; Favre 1938). 


\section{cultural contamination, children and the dangers of metissage}

[Young colonial men] are often driven to seek a temporary companion among women of color; this is the path by which, as I shall presently show, contagion travels back and forth, contagion in all senses of the word [Maunier 1932:171].

Racial degeneracy was thought to have social causes and political consequences, both tied to the domestic arrangements of colonialism in specific ways. Metissage (interracial unions) generally, and concubinage in particular, represented the paramount danger to racial purity and cultural identity in all its forms. It was through sexual contact with women of color that French men "contracted" not only disease but debased sentiments, immoral proclivities and extreme susceptibility to decivilized states (Dupuy 1955:198).

By the early 20th century, concubinage was denounced for undermining precisely those things that it was charged with fortifying decades earlier. Local women who had been considered protectors of men's well-being, were now seen as the bearers of ill health and sinister influences; adaptation to local food, language, and dress, once prescribed as healthy signs of acclimatization, were now sources of contagion and loss of (white) self. The benefits of local knowledge and sexual release gave way to the more pressing demands of respectability, the community's solidarity and its mental health. Increasingly French men in Indochina who kept native women were viewed as passing into "the enemy camp" (Pujarniscle 1931:107). Concubinage became the source not only of individual breakdown and ill-health, but the biological and social root of racial degeneration and political unrest. Children born of these unions were "the fruits of a regrettable weakness" (Mazet 1932:8), physically marked and morally marred with "the defaults and mediocre qualities of their [native] mothers" (Douchet 1928:10).

Concubinage was not as economically tidy and politically neat as colonial policy makers had hoped. It concerned more than sexual exploitation and unpaid domestic work; it was about children-many more than official statistics often revealed—and who was to be acknowledged as a European and who was not. Concubine children posed a classificatory problem, impinging on political security and white prestige. The majority of such children were not recognized by their fathers, nor were they reabsorbed into local communities as authorities often claimed. Although some European men legally acknowledged their progeny, many repatriated to Holland, Britain or France and cut off ties and support to mother and children (Brou 1907; Ming 1983:75). Native women had responsibility for, but attenuated rights over, their own offspring. They could neither prevent their children from being taken from them nor contest paternal suitability for custody. While the legal system favored a European upbringing, it made no demands on European men to provide it; many children became wards of the state, subject to the scrutiny and imposed charity of the European-born community at large.

Concubine children were invariably counted among the ranks of the European colonial poor, but European paupers in the late 19th century Netherlands Indies came from a far wider strata of colonial society than that of concubines alone (Rapport der Pauperisme-Commissie 1903). Many Indo-Europeans had become increasingly marginalized from strategic political and economic positions in the early 20th century despite new educational opportunities encouraged at the turn of the century. In the 1920s and 1930s Indies-born and educated youth were uncomfortably squeezed between an influx of new colonial recruits from Holland and the educated inlander ("native") population with whom they were in direct competition for jobs (Mansvelt 1932:295). ${ }^{24}$ At the turn of the century, volumes of official reports were devoted to documenting and alleviating the proliferation on Java of a "rough" and "dangerous pauper element" among (Indo) European clerks, low-level officials and vagrants (Encyclopedie van Nederland-Indie 1919:367).

European pauperism in the Indies reflected broad inequalities in colonial society, underscoring the social heterogeneity of the category "European" itself. Nonetheless, as late as 1917, concubinage was still seen by some as its major cause and as the principal source of "blankenhaters" (white-haters) (Braconier 1917:298). Concubinage became equated with a progeny of 
"malcontents," of "parasitic" whites, idle and therefore dangerous. The fear of concubinage was carried yet a step further and tied to the political fear that such Eurasians would demand economic access, political rights and express their own interests through alliance with (and leadership of) organized opposition to Dutch rule (Mansvelt 1932; Blumberger 1939). ${ }^{25}$

Racial prejudice against métis was often, as in the Belgian Congo, "camouflaged under protestations of 'pity' for their fate, as if they were 'malheureux' [unhappy] beings by definition" (Vellut 1982:103). As objects of charity, their protection in Indochina was a cause célèbre of European women-feminists and staunch colonial supporters-at home and abroad (Knibiehler and Goutalier 1985:37). European colonial women were urged to oversee their "moral protection," to develop their "natural" inclination toward French society, to turn them into "partisans of French ideas and influence" instead of revolutionaries (Chenet 1936:8; Sambuc 1931:261). The gender breakdown is clear: moral instruction reflected fears of sexual promiscuity in métisse girls and the political threat of métis boys turned militant men.

Orphanages for abandoned European and Indo-European children were not new features of 20th century colonial cultures; however, their importance increased vastly as an ever larger number of illegitimate children of mixed parentage populated grey zones along colonial divides. In the Netherlands Indies by the mid-18th century, state orphanages for Europeans were established to prevent "neglect and degeneracy of the many free-roaming poor bastards and orphans of Europeans" (quoted in Braconier 1917:293). By the 19th century, church, state and private organizations had become zealous backers of orphanages, providing some education but stronger doses of moral instruction. In India, civil asylums and charity schools cared for European and Anglo-Indian children in "almost every town, cantonment and hill-station" (Arnold 1979:108). In French Indochina in the 1930s virtually every colonial city had a home and society for the protection of abandoned métis youth (Chenet 1936; Sambuc 1931:256-272; Malleret 1934:220).

Whether these children were in fact "abandoned" by their Asian mothers is difficult to establish; the fact that métis children living in native homes were often sought out by state and private organizations and placed in these institutions to protect them against the "demoralised and sinister" influences of native kampung life suggests another interpretation (Taylor 1983). Public assistance in India, Indochina and the Netherlands Indies was designed not only to keep fair skinned children from running barefooted in native villages but to ensure that the proliferation of European pauper settlements was curtailed and controlled. ${ }^{26}$ The preoccupation with creating a patriotic loyalty to French and Dutch culture among children was symptomatic of a more general fear; namely, that there were already patricides of the colonial fatherland in the making; that as adult women these children would fall into prostitution; that as adult men with emotional ties to native women and indigenous society they would join the enemies of the state, verbasterd (degenerate) and décivilisé (Braconier 1917:293; Pouvourville 1926; Sambuc 1931:261; Malleret 1934).

\section{European motherhood and middle-class morality}

"A man remains a man as long as he is under the watch of a woman of his race" [George Hardy quoted in Chivas-Baron 1929:103],

Rationalization of imperial rule and safeguards against racial degeneracy in European colonies merged in the emphasis on particular moral themes. Both entailed a reassertion of European conventions, middle-class respectability, more frequent ties with the metropole and a restatement of what was culturally distinct and superior about how colonials ruled and lived. For those women who came to join their spouses or to find husbands, the prescriptions were clear. Just as new plantation employees were taught to manage the natives, women were schooled in colonial propriety and domestic management. French manuals, such as those on colonial hygiene in Indochina, outlined the duties of colonial wives in no uncertain terms. As 
"auxiliary forces" in the imperial effort they were to "conserve the fitness and sometimes the life of all around them" by ensuring that "the home be happy and gay and that all take pleasure in clustering there" (Grall 1908:66; Chailley-Bert 1897). Practical guides to life in the Belgian Congo instructed (and indeed warned) la femme blanche that she was to keep "order, peace, hygiene and economy" (Favre 1938:217), "perpetuate a vigorous race," while preventing any "laxity in our administrative mores" (Favre 1938:256; Travaux du Groupe d'Etudes coloniales 1910:10).

This "division of labor" contained obvious asymmetries. Men were considered more susceptible to moral turpitude than women who were thus held responsible for the immoral states of men. European women were to create and protect colonial prestige, insulating their men from cultural and sexual contact with the colonized (Travaux . . coloniales 1910:7). Racial degeneracy would be curtailed by European women charged with regenerating the physical health, the metropolitan affinities and the imperial purpose of their men (Hardy 1929:78).

At its heart was a reassertion of racial difference which harnessed nationalistic rhetoric and markers of middle-class morality to its cause (Delavignette 1946:47, Louffi 1971:112; Mosse 1978:86). George Mosse describes European racism in the early 20th century as a "scavenger ideology," annexing nationalism and bourgeois respectability such that control over sexuality was central to all three $(1985: 10,133-152)$. If the European middle class sought respectability "to maintain their status and self-respect against the lower-classes, and the aristocracy," in the colonies respectability was a defense against the colonized, and a way of more clearly defining themselves (Mosse 1985:5). Good colonial living now meant hard work, no sloth, and physical exercise rather than sexual release, which had been one rationale for condoning concubinage and prostitution in an earlier period. The debilitating influences of climate could be surmounted by regular diet and meticulous personal hygiene over which European women were to take full charge. Manuals on how to run a European household in the tropics provided detailed instructions in domestic science, moral upbringing and employer-servant relations. Adherence to strict conventions of cleanliness and cooking occupied an inordinate amount of women's time (Hermans 1925; Ridley 1983:77). Both activities entailed a constant surveillance of native nursemaids, laundrymen and live-in servants, while reinforcing the domestication of European women themselves (Brink 1920:43).

Leisure, good spirit, and creature comforts became the obligation of women to provide, the racial duty of women to maintain. Sexual temptations with women of color would be curtailed by a happy family life, much as "extremist agitation" on Sumatra's estates was to be averted by selecting married recruits and by providing family housing to permanent workers (Stoler 1985a). Moral laxity would be eliminated through the example and vigilance of women whose status was defined by their sexual restraint, and dedication to their homes and to their men.

The perceptions and practice that bound women's domesticity to national welfare and racial purity were not applied to colonial women alone. Childrearing in late 19th century Britain was hailed as a national, imperial, and racial duty, as it was in Holland, the U.S. and Germany at the same time (Davin 1978:13; Smith-Rosenberg 1973:35], Bock 1984:274; Stuurman 1985). In France, where declining birth rates were of grave concern, popular colonial authors such as Pierre Mille pushed mothering as women's "essential contribution to the imperial mission of France" (Ridley 1983:90). With motherhood at the center of empire building, pronatalist policies in Europe forced some improvement in colonial medical facilities, the addition of maternity wards, increased information and control over the reproductive conditions of European and colonized women alike. Maternal and infant health programs instructed European women in the use of milk substitutes, wet nurses and breastfeeding practices in an effort to encourage more women to stay in the colonies and in response to the many more that came (Hunt 1988). But the belief that the colonies were medically hazardous for white women meant that motherhood in the tropics was not only a precarious but a conflicted endeavor. French women 
bound for Indochina were warned that they would only be able to fulfill their maternal duty "with great hardship and damage to [their] health" (Grall 1908:65)

Real and imagined concern over individual reproduction and racial survival contained and compromised white colonial women in a number of ways. Tropical climates were said to cause low fertility, prolonged amenorrhea and permanent sterility (Rodenwalt 1928:3; Hermans 1925:123). Belgian doctors confirmed that "the woman who goes to live in a tropical climate is often lost for the reproduction of the race" (Knibiehler and Goutalier 1985:92; Vellut 1982:100). The climatic and medical conditions of colonial life were associated with high infant mortality, such that "the life of a European child was nearly condemned in advance" (Grall 1908:65; Price 1939:204).

These perceived medical perils called into question whether white women and thus "white races" could actually reproduce if they remained in the tropics for extended periods of time. An international colonial medical community cross-referenced one another in citing evidence of racial sterility by the second or third generation (Harwood 1938:132; Cranworth quoted in Kennedy 1987:115). While such a dark view of climate was not prevalent in the Indies, psychological and physical adaptation was never a given. Dutch doctors repeatedly quoted German physicians, if not to affirm the inevitable infertility among whites in the tropics, at least to support their contention that European-born women and men (totoks) should never stay in the colonies too long (Hermans 1925:123). Medical studies in the 1930s, such as that supported by the Netherlands Indies Eugenic Society, were designed to test whether fertility rates differed by "racial type" between Indo-European and European-born women, and whether children of certain Europeans born in the Indies displayed different "racial markers" than their parents (Rodenwalt 1928:4).

Like the discourse on degeneracy, the fear of sterility was less about the biological survival of whites than about their political viability and cultural reproduction. These concerns were evident in the early 1900 s, coming to a crescendo in the 1930 s when white unemployment hit the colonies and the metropole at the same time. The depression made repatriation of impoverished French and Dutch colonial agents unrealistic, prompting speculation as to whether European working classes could be relocated in the tropics without causing further racial degeneration (Winckel 1938; Price 1939). Although white migration to the tropics was reconsidered, poor white settlements were rejected on economic, medical and psychological grounds (Feuilletau de Bruyn 1938:27). Whatever the solution, such issues hinged on the reproductive potential of European women, invasive questionnaires (which many women refused to answer) concerning their "acclimatization," and detailed descriptions of their sexual lives.

Imperial perceptions and policies fixed European women in the colonies as "instruments of race-culture" in what proved to be personally difficult and contradictory ways (Hammerton 1979). Childrearing manuals faithfully followed the sorts of racist principles that constrained the activities of women charged with childcare (Grimshaw 1983:507). Medical experts and women's organizations recommended strict surveillance of children's activities (Mackinnon 1920:944) and careful attention to those with whom they played. Virtually every medical and household handbook in the Dutch, French and British colonies in the early 20th century warned against leaving small children in the unsupervised care of local servants. In the Netherlands Indies, it was the "duty" of the hedendaagsche blanke moeder (modern white mother) to take the physical and spiritual upbringing of her offspring away from the babu (native nursemaid) and into her own hands (Wanderken 1943:173). Precautions had to be taken against "sexual danger," uncleanly habits of domestics, against a "stupid negress" who might leave a child exposed to the sun (Bauduin 1941; Berenger-Féraud 1875:491). Even in colonies where the climate was not considered unhealthy, European children supposedly thrived well "only up to the age of six" when native cultural influences came into stronger play (Price 1939:204; Grimshaw 1983:507). In the Dutch East Indies, where educational facilities for European children were considered excellent, some still deemed it imperative to send them back to Holland 
to avoid the "precocity" associated with the tropics and the "danger" of contact with Indische youths not from "full-blooded European elements" (Baudin 1941:63).

We Dutch in the Indies live in a country which is not our own . . . we feel instinctively that our blonde, white children belong to the blonde, white dunes, the forests, the moors, the lakes, the snow.... A Dutch child should grow up in Holland. There they will acquire the characteristics of their race, not only from mother's milk but also from the influence of the light, sun and water, of playmates, of life, in a word, in the sphere of the fatherland. This is not racism. . . [Baudin 1941:63-4]

But even in the absence of such firm convictions, how to assure the "moral upbringing" of European children in the colonies remained a primary focus of women's organizations in the Indies and elsewhere right through decolonization. ${ }^{27}$ In many colonial communities, school age children were packed off to Europe for education and socialization. In those cases European women were confronted with a difficult set of choices which entailed separation either from their children or husbands. Frequent trips between colony and metropole not only separated families, but also broke up marriages and homes (Malleret 1934:164; Grimshaw 1983:507; Callaway 1987:183-184). The important point is that the imperial duty of women to closely surveil husbands, servants and children profoundly affected the social space they occupied and the economic activities in which they could feasibly engage.

\section{shifting strategies of rule and sexual morality}

Though sex cannot of itself enable men to transcend racial barriers, it generates some admiration and affection across them, which is healthy, and which cannot always be dismissed as merely self-interested and prudential. On the whole, sexual interaction between Europeans and non-Europeans probably did more good than harm to race relations; at any rate, I cannot accept the feminist contention that it was fundamentally undesirable [Hyam 1986a:75].

The political etymology of colonizer and colonized was gender and class specific. The exclusionary politics of colonialism demarcated not just external boundaries but interior frontiers, specifying internal conformity and order among Europeans themselves. I have tried to show that the categories of colonizer and colonized were secured through notions of racial difference constructed in gender terms. Redefinitions of sexual protocol and morality emerged during crises of colonial control precisely because they called into question the tenuous artifices of rule within European communities and what marked their borders. Even from the limited cases we have reviewed, several patterns emerge. First and most obviously, colonial sexual prohibitions were racially assymetric and gender specific. Thus racial attributes were rarely discussed in nongendered terms; one was always a black man, an Asian woman. Secondly, interdictions against interracial unions were rarely a primary impulse in the strategies of rule. Interracial unions (as opposed to marriage) between European men and colonized women aided the long-term settlement of European men in the colonies while ensuring that colonial patrimony stayed in limited and selective hands. In India, Indochina and South Africa in the early centuries-colonial contexts usually associated with sharp social sanctions against interracial unions- - "mixing" was systematically tolerated and even condoned. ${ }^{28}$

Changes in sexual access and domestic arrangements have invariably accompanied major efforts to reassert the internal coherence of European communities and to redefine the boundaries of privilege between the colonizer and the colonized. Sexual union in itself, however, did not automatically produce a larger population legally classified as "European." On the contrary, miscegenation signaled neither the absence nor presence of racial prejudice in itself; hierarchies of privilege and power were written into the condoning of interracial unions, as well as into their condemnation.

While the chronologies vary from one colonial context to another, we can identify some parallel shifts in the strategies of rule and in sexual morality. Concubinage fell into moral disfavor at the same time that new emphasis was placed on the standardization of European administration. While this occurred in some colonies by the early 20th century and in others 
later on, the correspondence between rationalized rule, bourgeois respectability and the custodial power of European women to protect their men seems strongest during the interwar years when Western scientific and technological achievements were then in question, and native nationalist and labor movements were hard pressing their demands. ${ }^{29}$ Debates concerning the need to systematize colonial management and dissolve the provincial and personalized satraps of "the old-time colon" in the French empire invariably targeted and condemned the unseemly domestic arrangements in which they lived. British high colonial officials in Africa imposed new "character" requirements on their subordinates, designating specific class attributes and conjugal ties that such a selection implied (Kuklick 1979). Critical to this restructuring was a new disdain for colonials too adapted to local custom, too removed from the local European community, and too encumbered with intimate native ties. As in Sumatra, this hands-off policy distanced Europeans in more than one sense: it forbade European staff both from personal confrontations with their Asian fieldhands and from the limited local knowledge they gained through sexual ties.

At the same time, medical expertise confirmed the salubrious benefits of European comradery and frequent home leaves, of a cordon sanitaire, not only around European enclaves, but around each home. White prestige became defined by this rationalized management and by the moral respectability and physical well-being of its agents, with which European women were charged. Colonial politics locked European men and women into a routinized protection of their physical health and social space in ways which bound gender prescriptions to class conventions, thereby fixing the racial cleavages between "us" and "them."

I have focused here on the multiple levels at which sexual control figured in the substance, as well as the iconography, of racial policy and imperial rule. But colonial politics was obviously not just about sex; nor did sexual relations reduce to colonial politics. On the contrary, sex in the colonies was about sexual access and reproduction, class distinctions and racial privileges, nationalism and European identity in different measure and not all at the same time. These major shifts in the positioning of women were not signaled by the penetration of capitalism per se but by more subtle changes in class politics, imperial morality and as responses to the vulnerabilities of colonial control. As we attempt broader ethnographies of empire, we may begin to capture how European culture and class politics resonated in colonial settings, how class and gender discriminations not only were translated into racial attitudes, but themselves reverberated in the metropole as they were fortified on colonial ground. Such investigations should help show that sexual control was both an instrumental image for the body politic, a salient part standing for the whole, and itself fundamental to how racial policies were secured and how colonial projects were carried out.

\section{notes}

'Here I focus primarily on the dominant male discourse (and less on women's perceptions of social and legal constraints) since it was the structural positioning of European women in colonial society and how their needs were defined for, not by, them which most directly accounted for specific policies.

2See Verena Martinez-Alier (1974) on the subtle and changing criteria by which color was assigned in 19 th century Cuba. Also see A. van Marle (1952) on shifting cultural markers of European membership in the 19 th and early 20 th century Netherlands Indies.

${ }^{3}$ See Malleret (1934:216-241). See also Tiffany and Adams who argue that "the Romance of the Wild Woman" expressed critical distinctions between civilization and the primitive, culture and nature, and the class differences between repressed middle-class women and "her regressively primitive antithesis, the working-class girl" (Tiffany and Adams 1985:13).

"Many of these studies focus on South Africa and tend to provide more insight into the composition of the black labor force than into the restrictions on European women themselves (Cock 1980; Gaitskell 1983; Hansen 1986). Important exceptions are those which have traced historical changes in colonial prostitution and domestic service where restrictions were explicitly class specific and directly tied racial policy to sexual control (Ming 1983; Van Heyningen 1984; Hesselink 1987; Schmidt 1987). 
${ }^{5}$ As Tessel Pollman suggests, the term nyai glossed several functions: household manager, servant, housewife, wife and prostitute. Which of these was most prominent depended on the character of both partners and on the prosperity of the European man (1986:100). Most colonized women, however, combining sexual and domestic service within the abjectly subordinate contexts of slave or "coolie," lived in separate quarters, and exercised very few legal rights; they could be dismissed without reason or notice, were exchanged among European employers and most significantly, as stipulated in the Indies Civil Code of 1848, "had no rights over children recognized by a white man" (Taylor 1977:30). On Java, however, some nyai achieved some degree of limited authority, managing the businesses as well as the servants and household affairs of better-off European men (Nieuwenhuys 1959:17; Lucas 1986:86; Taylor 1983).

${ }^{6}$ While prostitution served some of the colonies for some of the time, it was economically costly, medically unwieldy and socially problematic. Veneral disease was difficult to check even with the elaborate system of lock hospitals and contagious disease acts of the British empire and was of little interest to those administrations bent on promoting permanent settlement (Ballhatchet 1980; Ming 1983). When concubinage was condemned in the 1920 s in India, Malaya and Indonesia, venereal disease spread rapidly, giving rise to new efforts to reorder the domestic arrangements of European men (Butcher 1979:217; Ming 1983; Braconier 1933; Ballhatchet 1980).

"See Ritter who describes these arrangements in the mid-19th century as a "necessary evil" with no emotional attachments, because for the native woman, "the meaning of our word 'love' is entirely unknown" (1856:21).

In the case of the Indies, interracial marriages increased at the same time that concubinage fell into sharp decline (van Marle 1952). This rise was undoubtedly restricted to Indisch Europeans (those born in the Indies) who may have been eager to legalize preexisting unions in response to the moral shifts accompanying a more European cultural climate of the 1920s (van Doorn 1985). It undoubtedly should not be taken as an indication of less closure among the highly endogamous European-born population of that period (I owe this distinction in conjugal patterns to Wim Hendrik).

${ }^{9}$ On the differences between Java's European community which was sharply divided between the totoks (full-blooded Dutch born in Holland) and the Indisch majority (Europeans of mixed parentage and/or those Dutch born in the Indies), and Sumatra's European-oriented and non-Indisch colonial community see Muller (1912), Wertheim (1959), van Doorn (1985), Stoler (1985b).

${ }^{10}$ Similarly, one might draw the conventional contrast between the different racial policies in French, British and Dutch colonies. However, despite French assimilationist rhetoric, Dutch tolerance of intermarriage, and Britain's overtly segregationist stance, the similarities in the actual maintenance of racial distinctions through sexual control in these varied contexts is perhaps more striking than the differences. For the moment, it is there similarities with which I am concerned. See, for example, Simon (1981:46-48) who argues that although French colonial rule was generally thought to be more racially tolerant than that of Britain's, racial distinctions in French Indochina were in practice vigorously maintained.

"Cf. Degler who also attributes the tenor of race relations to the attitudes of European women; not, however, because they were inherently more racist, but because in some colonial contexts they were able to exert more influence over the extramarital affairs of their men (1986[1971]:238).

${ }^{12} \mathrm{Although}$ some Dutch women in fact championed the cause of the wronged nyai, urging improved protection for nonprovisioned women and children, they rarely went so far as to advocate for the legitimation of these unions in legal marriage (Taylor 1977:31-32, Lucas 1986:95).

${ }^{13}$ Archive d'Outre Mer "Emigration des femmes aux colonies" 1897-1904:GG9903, 1893-4:GG7663.

${ }^{14}$ See the French Archive d'Outre Mer, Series S.65 "Free Passage accorded to Europeans," including dossiers on "free passage for impoverished Europeans," for example GG 9925, 1897; GG 2269, 18991903).

${ }^{15} \mathrm{Cf}$. Van Onselen (1982:103-162) who argues that the presence of European prostitutes and domesticsturned-prostitutes in South Africa was secured by a large, white working-class population, and a highly unstable labor market for white working-class women (1982:103-162). Also see Van Heyningen who ties changes in the history of prostitution among continental women in the Cape Colony to new notions of racial purity and the large-scale urbanization of blacks after the turn of the century (1984:192-195).

${ }^{16}$ As George Mosse notes, the concept of racial degeneration had been tied to miscegenation by Gobineau and others in the early 1800 s but gained common currency in the decades that followed, entering European medical and popular vocabulary at the turn of the century (1978:82-88).

${ }^{17}$ British eugenicists petitioned to refuse marriage licenses to the mentally ill, vagrants and the chronically unemployed (Davin 1978:16; Stepan 1982:123). In the U.S. a model eugenic sterilization law from 1922 targeted among others "orphans, homeless and paupers," while in Germany during the same period "sterilization was widely and passionately recommended as a solution to shiftlessness ... illegitimate birth. .. , poverty; and the rising costs of social services" (Bajema 1976:138; Bock 1984:274).

${ }^{18}$ The active interest of French anthropologists in the relationship between eugenics and immigration (and therefore in the U.S. sterilization laws, in particular) was not shared in the Netherlands (see Schneider [1982] on the particularities of eugenics in France). On the other hand, for some examples of eugenically informed race studies in the Dutch colonial context see Ons Nageslacht, the Geneeskundig Tijdschrift voor Nederlandsh-Indie, as well as the numerous articles relating to "the Indo problem" which appeared in the Indies popular and scientific press during the 1920 s and 1930s. 
${ }^{19}$ The topics covered in the bulletin of the Netherlands Indies Eugenics society gives some sense of the range of themes included in these concerns: articles appearing in the 1920s and 30s discussed, among other things, "biogenealogical" investigations, the complementarity between Christian thought and eugenic principles, ethnographic studies of mestizo populations, and not least importantly, the role of IndoEuropeans in the anti-Dutch rebellions (Ons Nageslacht 1928-32).

${ }^{20}$ See Mosse (1985) for an examination of the relationship between manliness, racism and nationalism in the European context.

${ }^{21}$ The relationship between physical appearance and moral depravity was not confined to evaluations of European colonials alone. Eugenic studies abounded in speculations on the specific physical traits signaling immorality in the European lower orders, while detailed descriptions of African and Asian indigenous populations paired their physical attributes with immoral and debased tendencies.

${ }^{22}$ Adherence to the idea that "tropical neurasthenia" was a specific malady was not shared by all medical practitioners. Among those who suggested that the use of the term be discontinued did so on the belief that neurasthenia in the tropics was a pyschopathology caused by social, not physiological, maladjustment (Culpin [1926] cited in Price 1939:211).

${ }^{23}$ On the social geography of hill stations in British India and on the predominance of women and children in them, see King 1976:156-179.

${ }^{24}$ European pauperism in the Indies at the turn of the century referred primarily to a class of Indo-Europeans marginalized from the educated and "developed" elements in European society (Blumberger 1939:19). However, pauperism was by no means synonymous with Eurasian status since nearly 80 percent of the "Dutch" community were of mixed descent, some with powerful political and economic standing (Braconier 1917:291). As Jacques van Doorn notes "it was not the Eurasian as such, but the "Kleine Indo" [poor Indo] who was the object of ridicule and scorn in European circles" (1983:8). One could argue that it was as much Eurasian power as pauperism that had to be checked.

${ }^{25}$ French government investigations, accordingly, exhibited a concern for "the métis problem" which was out of proportion with the numbers of those who fell in that category. While the number of "Indos" in the Indies was far greater, there was never any indication that this social group would constitute the vanguard of an anticolonial movement.

${ }^{26}$ In colonial India, "orphanages were the starting-point for a lifetime's cycle of institutions" in which "unseemly whites" were secluded from Asian sight and placed under European control (Arnold 1979:113). In Indonesia, Pro Juventate branches supported and housed together "neglected and criminal" youth with special centers for Eurasian children.

${ }^{27} \mathrm{See}$, for example, the contents of women's magazines such as the Huisvrouw in Deli for which the question of education in Holland or the Indies was a central issue. The rise of specific programs (such as the Clerkx-methode voor Huisonderwiis) designed to guide European mothers in the home instruction of their children may have been a response to this new push for women to oversee directly the moral upbringing of their children.

20I have focused on late colonialism in Asia, but colonial elite intervention in the sexual life of their agents and subjects was by no means confined to this place or period. See Nash $(1980: 141)$ on changes in mixed marriage restrictions in 16th-century Mexico and Martinez-Alier on interracial marriage prohibitions in relationship to slave labor supplies in 18th- and early 19th-century Cuba (1974:39).

${ }^{29}$ See Adas (1989) for a discussion of major shifts in colonial thinking during this period.

\title{
references
}

\author{
Abatucci \\ 1910 Le milieu africain consideré au point de vue de ses effets sur le système nerveux de l'européen. \\ Annales d'Hygiène et de Médecine Coloniale 13, 328-335. \\ Adas, Michael \\ 1989 Machines as the Measure of Men: Scientific and Technological Superiority and Ideologies of \\ Western Dominance. Ithaca: Cornell University Press. \\ Arnold, David \\ 1979 European Orphans and Vagrants in India in the Nineteenth Century. The Journal of Imperial and \\ Commonwealth History 7:2, 104-27. \\ 1983 White Colonization and Labour in Nineteenth-Century India. Journal of Imperial and Common- \\ wealth History $11: 2,133-158$. \\ Bajema, Carl, ed. \\ 1976 Eugenics Then and Now. Stroudsburg, PA: Dowden, Hutchinson \& Ross. \\ Ballhatchet, Kenneth \\ 1980 Race, Sex and Class under the Raj: Imperial Attitudes and Policies and Their Critics, 1793-1905. \\ New York: St. Martin's Press. \\ Baroli, Marc \\ 1967 La vie quotidienne des Français en Algérie. Paris: Hachette.
}


Bauduin, D. C. M.

1941(1927) Het Indische Leven. 'S-Gravenhage: H. P. Leopolds.

Beidelman, Thomas

1982 Colonial Evangelism. Bloomington: Indiana University Press.

Bérenger-Féraud, $\mathrm{L}$.

1875 Traité Clinique des Maladies des Européens au Sénégal. Paris: Adrien Delahaye.

Blumberger, J. Th. Petrus

1939 De Indo-Europeesche Beweging in Nederlandsch-Indie. Haarlem: Tjeenk Willink.

Blussé, Leonard

1986 Strange Company: Chinese Settlers, Mestizo Women and the Dutch in VOC Batavia. Dordrecht: Foris.

Bock, Gisela

1984 Racism and Sexism in Nazi Germany: Motherhood, Compulsory Sterilization, and the State. In When Biology Became Destiny: Women in Weimar and Nazi Germany. New York: Monthly Review Press, 271-296.

Boutilier, James

1984 European Women in the Solomon Islands, 1900-1942. In Rethinking Women's Roles: Perspectives from the Pacific. O'Brien, Denise and Sharon Tiffany, eds. Pp. 173-199. Berkeley: University of California Press.

Braconier, A. de

1913 Het Kazerne-Concubinaat in Ned-Indie. Vragen van den Dag 28, 974-95.

1917 Het Pauperisme onder de in Ned. Oost-Indie levende Europeanen. In Nederlandsch-Indie (1st yr.), 291-300.

1918 Kindercriminaliteit en de verzorging van misdadiq aangelegde en verwaarloosde minderjarigen in Nederlansch Indie. Baarn: Hollandia-Drukkerij.

1933 Het Prostitutie-vraagstuk in Nederlandsch-Indie Indisch Gids 55:2, 906-928.

Brink, K.B.M. Ten

1920 Indische Gezondheid. Batavia: Nillmij.

Brou, A. M. N.

1907 Le Métis Franco-Annamite. Revue Indochinois. (July 1907):897-908.

Brownfoot, Janice N.

1984 Memsahibs in Colonial Malaya: A Study of European Wives in a British Colony and Protectorate 1900-1940. The Incorporated Wife. Hilary Callan and Shirley Ardener, eds. London: Croom Helm.

Butcher, John

1979 The British in Malaya, 1880-1941: The Social History of a European Community in Colonial Southeast Asia. Kuala Lumpur: Oxford UP.

Callan, Hilary and Shirley Ardener

1984 The Incorporated Wife. London: Croom Helm.

Callaway, Helen

1987 Gender, Culture and Empire: European Women in Colonial Nigeria. London: Macmillan Press.

Chailley-Bert, M. J.

1897 L'Emigration des femmes aux colonies. Union Coloniale Francaise-conférence, 12 January 1897. Paris: Armand Colin.

Chenet, $\mathrm{Ch}$.

1936 Le role de la femme française aux Colonies: Protection des enfants métis abandonnés. Le Devoir des Femmes, 15 February 1936, p. 8.

Clerkx, Lily

1961 Mensen in Deli. Amsterdam: Sociologisch-Historisch Seminarium voor Zuidoost-Azie. Publication no. 2.

Chivas-Baron, Clotide

1929 La femme française aux colonies. Paris: Larose.

Cock, J.

1980 Maids and Madams. Johannesburg: Ravan Press.

Cohen, William

1971 Rulers of Empire: The French Colonial Service in Africa. Stanford: Hoover Institution Press.

1980 The French Encounter with Africans. White Response to Blacks, 1530-1880. Bloomington: Indiana University Press.

Cool, F.

1938 De Bestrijding der Werkloosheidsgevolgen in Nederlandsch-Indie gedurende 1930-1936. De Economist, 135-47; 217-243.

Cooper, Frederick

1980 From Slaves to Squatters. New Haven: Yale University Press.

Corneau, Grace

1900 La femme aux colonies. Paris: Librairie Nilsson.

Courtois, E.

1900 Des Règles Hygiéniques que doit suivre l'Européen au Tonkin. Revue Indo-chinoise 83, 539 $541 ; 564-566 ; 598-601$. 
Davin, Anna

1978 Imperialism and Motherhood. History Workshop 5, 9-57.

Degler, Carl

1971 Neither Black nor White. New York: Macmillan.

Delavignette, Robert

1946 Service Africain. Paris: Gallimard.

Dixon, C. J.

1913 De Assistent in Deli. Amsterdam: J.H. de Bussy.

Douchet

1928 Métis et congaies d'Indochine. Hanoi.

Dowd Hall, Jacquelyn

1984 "The Mind that Burns in Each Body": Women, Rape, and Racial Violence. Southern Exposure $12: 6,61-71$

Drooglever, $P$

1980 De Vaderlandse Club, 1929-42. Franeker: T. Wever.

Dupuy, Aimé

1955 La personnalité du colon. Revue d'Histoire Economique et Sociale 33:1, 77-103.

Encylopedie van Nederland-Indie.

1919 S'Gravenhage: Nijhoff and Brill.

Etienne, Mona and Eleanor Leacock

1980 Women and Colonization. N.Y.: Praeger.

Fanon, Franz

1967[1952] Black Skin, White Masks. New York: Grove Press.

Favre, J. L.

1938 La Vie aux Colonies. Paris: Larose.

Feuilletau de Bruyn, W.

1938 Over de Economische Mogelijkheid van een Kolonisatie van Blanken op Nederlandsch NieuwGuinea. In Comptes Rendus du Congrès International de Géographie, Amsterdam. Leiden: Brill, $21-$ 29.

Fredrickson, George

1981 White Supremacy. New York: Oxford University Press.

Gaitskell, Deborah

1983 Housewives, Maids or Mothers: Some Contradictions of Domesticity for Christian Women in Johannesburg, 1903-39. Journal of African History 24, 241-256.

Gann, L. H. and Peter Duignan

1978 The Rulers of British Africa, 1870-1914. Stanford: Stanford University Press.

Gantes, Gilles de

1981 La population française au Tonkin entre 1931 et 1938. Memoire. Aix-en-Provence: Institut d'Histoire des Pays d'Outre Mer.

Gartrell, Beverley

1984 Colonial Wives: Villains or Victims? The Incorporated Wife. H. Callan, and S. Ardener. London: Croom Helm, 165-185.

Gilman, Sander L.

1985 Difference and Pathology. Ithaca: Cornell University Press.

Gordon, Linda

1976 Woman's Body, Woman's Right. New York: Grossman.

Gordon, R. and M. Meggitt

1985 Law and Order in the New Guinea Highlands. Hanover: University Press of New England.

Grall, Ch.

1908 Hygiène Coloniale appliquée. Paris: Baillière.

Grimshaw, Patricia

1983 Christian Woman, Pious Wife, Faithful Mother, Devoted Missionary: Conflicts in Roles of American Missionary Women in Nineteenth-Century Hawaii. Feminist Studies, 9:3, 489-521.

Hammerton, James

1979 Emigrant Gentlewomen. London: Croom Helm.

Hansen, Karen Tranberg

1986 Household Work as a Man's Job: Sex and Gender in Domestic Service in Zambia. Anthropology Today $2: 3,18-23$

Hardy, George

1929 Ergaste ou la Vocation Coloniale. Paris: Armand Colin.

Hartenberg

1910 Les Troubles Nerveux et Mentaux chez les coloniaux. Paris.

Harwood, Dorothy

1938 The Possibility of White Colonization in the Tropics. Comptes Rendu du Congrès Int'I de Géographie. Leiden: Brill, 131-140.

Hermans, E. $\mathrm{H}$.

1925 Gezondscheidsleer voor Nederlandsch-Indie. Amsterdam: Meulenhoff. 
Hesselink, Liesbeth

1987 Prostitution: A Necessary Evil, Particularly in the Colonies: Views on Prostitution in the Netherlands Indies. In Indonesian Women in Focus. Locher-Scholten, E. and A. Niehof. Dordrecht: Foris, 205-224.

Het Pauperisme Commissie

1901 Het Pauperisme onder de Europeanen. Batavia: Landsdrukkerij.

1903 Rapport der Pauperisme-Commissie. Batavia: Landsdrukkerij.

Hobsbawn, Eric

1987 The Age of Empire, 1875-1914. London: Weidenfeld and Nicholson.

Hunt, Nancy

1988 Le bébé en brousse: European Women, African Birth Spacing and Colonial Intervention in Breast Feeding in the Belgian Congo. International Journal of African Historical Studies 21:3.

Hyam, Ronald

1986a Empire and Sexual Opportunity. The Journal of Imperial and Commonwealth History 14:2, 3490.

1986b Concubinage and the Colonial Service: The Crewe Circular (1909). The Journal of Imperial and Commonwealth History 14:3, 170-186.

Inglis, Amirah

1975 The White Women's Protection Ordinance: Sexual Anxiety and Politics in Papua. London: Sussex University Press.

Jaurequiberry

1924 Les Blancs en Pays Chauds. Paris: Maloine.

Jordan, Winthrop

1968 White over Black: American Attitudes Toward the Negro, 1550-1812. Chapel Hill: University of North Carolina Press.

Joyeux, Ch. and A. Sice

1937 Affections exotiques du système nerveux. Précis de Médecine Coloniale. Paris: Masson.

Kantoor van Arbeid

1935 Werkloosheid in Nederlandsch-Indie. Batavia: Landsdrukkerij.

Kennedy, Dane

1987 Islands of White. Durham: Duke University Press.

Kennedy, Raymond

1947 The Ageless Indies. New York: John Day.

Kevles, Daniel

1985 In the Name of Eugenics. Berkeley: University of California Press.

King, Anthony

1976 Colonial Urban Development. London: Routledge \& Kegan Paul.

Kirkwood, Deborah

1984 Settler Wives in Southern Rhodesia: A Case Study. In The Incorporated Wife. Callan, H. and Ardener, S., eds. London: Croom Helm.

Knibiehler, Y. and R. Goutalier

1985 La femme au temps des colonies. Paris: Stock.

1987 Femmes et Colonisation: Rapport Terminal au Ministère des Relations Extérieures et de la Coopération. Aix en-Provence: Institut d'Histoire des Pays d'Outre-Mer.

Koks, Dr. J. Th.

1931 De Indo. Amsterdam: H.J. Paris.

Kroniek

1917 Oostkust van Sumatra-Instituut. Amsterdam: J.H. de Bussy.

Kuklick, Henrika

1979 The Imperial Bureaucrat: The Colonial Administrative Service in the Gold Coast, 1920-1939. Stanford: Hoover Institution Press.

Le Bras, Hervé

1981 Histoire secrète de la fécondité Le Débat 8:76-100.

Loutfi, Martine Astier

1971 Littérature et Colonialisme. Paris: Mouton.

Lucas, Nicole

1986 Trouwverbod, inlandse huishousdsters en Europese vrouwen. In Vrouwen in de Nederlandse KoIonien. Reijs, J. et al. Nijmegen: SUN, 78-97.

Mackinnon, Murdoch

1920 European Children in the Tropical Highlands. Lancet 199, 944-945.

Malleret, Louis

1934 L'Exotisme Indochinois dans la Littérature Française depuis 1860. Paris: Larose.

Mannoni, Octavio

1964 Prospero and Caliban. New York: Praeger.

Mansvelt, $W$.

1932 De Positie der Indo-Europeanen. Kolonial Studien, 290-311. 
Martinez-Alier, Verena

1974 Marriage, Class and Colour in Nineteenth Century Cuba. Cambridge: Cambridge University Press.

Mason, Philip

1958 The Birth of a Dilemma: The Conquest and Settlement of Rhodesia. New York: Oxford University Press.

Maunier, M. René

1932 Sociologie Coloniale. Paris: Domat-Montchrestien.

Mazet, Jacques

1932 La Condition Juridique des Métis. Paris: Domat Montchrestien.

Mercier, Paul

1965 The European Community of Dakar. In Africa: Social Problems of Change and Conflict. Berghe, Pierre van den, ed. San Francisco: Chandler, 284-304.

Ming, Hanneke

1983 Barracks-Concubinage in the Indies, 1887-1920. Indonesia 35 (April), 65-93.

Moore-Gilbert, B.J.

1986 Kipling and "Orientalism." New York: St. Martin's.

Mosse, George

1978 Toward the Final Solution. New York: Fertig.

1985 Nationalism and Sexuality. Madison: University of Wisconsin Press.

Muller, Hendrik

1912 De Europeesche Samenleving. Neerlands Indie. Amsterdam: Elsevier:371-384.

Nandy, Ashis

1983 The Intimate Enemy: Loss and Recovery of Self under Colonialism. Delhi: Oxford University Press.

Nash, June

1980 Aztec Women: The Transition from Status to Class in Empire and Colony. In Woman and Colonization: Anthropological Perspectives. Mona Etienne and Eleanor Leacock, eds. New York: Praeger, 134-148.

Nieuwenhuys, Roger

1959 Tussen Twee Vaderlanden. Amsterdam: Van Oorschot.

Nora, Pierre

1961 Les Français d'Algerie. Paris: Julliard.

O'Brien, Rita Cruise

1972 White Society in Black Africa: The French in Senegal. London: Faber \& Faber.

Pollmann, Tessel

1986 Bruidstraantjes: De Koloniale roman, de njai en de apartheid. In Vrouwen in de Nederlandse Kolonien. Reijs, J. et. al. eds. Nijmegen: SUN, 98-125.

Pourvourville, Albert de

1926 Le Métis. Le Mal d'Argent. Paris: Monde Moderne, 97-114.

Price, Grenfell A.

1939 White Settlers in the Tropics. New York: American Geographical Society.

Prochaska, David

1989 Making Algeria French: Colonialism in Bone, 1870-1920. Cambridge: Cambridge University Press.

Pujarniscle, E.

1931 Philoxène ou de la litterature coloniale. Paris.

Raptschinsky, B.

1941 Kolonisatie van blanken in de tropen. Den Haag: Bibliotheek van weten en denken.

Reijs, J., E. Kloek, U. Jansz, A. de Wildt, S. van Norden, M. de Baar

1986 Vrouwen in de Nederlandse Kolonien. Nijmegen:SUN.

Ridley, Hugh

1983 Images of Imperial Rule. New York: Croom \& Helm.

Ritter, W.L.

1856 De Europeaan in Nederlandsch Indie. Leyden: Sythoff.

Rodenwalt, Ernest

1928 Eugenetische Problemen in Nederlandsch-Indie. Ons Nageslacht. 1-8.

Said, Edward $W$.

1978 Orientalism. New York: Vintage.

Sambuc

1931 Les Métis Franco-Annamites en Indochine. Revue du Pacifique, 256-272.

Schneider, William

1972 Toward the Improvement of the Human Race: The History of Eugenics in France. Journal of Modern History 54:269-291.

Schoevers, $T$.

1913 Het leven en werken van den assistent bij de Tabakscultuur in Deli. Jaarboek der Vereeniging "Studiebelangen." Wageningen: Zomer, 3-43. 
Schmidt, Elizabeth

1987 Ideology, Economics and the Role of Shona Women in Southern Rhodesia, 1850-1939. Ph.D. dissertation, University of Wisconsin.

Simon, Jean-Pierre

1981 Rapatriés d'Indochine. Paris: Harmattan.

Sivan, Emmanuel

1983 Interpretations of Islam. Princeton: Darwin Press.

Smith-Rosenberg, Carroll and Charles Rosenberg

1973 The Female Animal: Medical and Biological Views of Woman and Her Role in Nineteenth-Century America. Journal of American History 60(2):332-356.

Spear, Percival

1963 The Nabobs. London: Oxford University Press.

Stepan, Nancy

1982 The Idea of Race in Science. London: Macmillan.

Stoler, Ann

1985a Capitalism and Confrontation in Sumatra's Plantation Belt, 1870-1979. New Haven: Yale University Press.

1985b Perceptions of Protest. American Ethnologist 12:4, 642-658.

1989 Rethinking Colonial Categories: European Communities and the Boundaries of Rule. Comp. Studies in Society and History 13(1):134-161.

Strobel, Margaret

1987 Gender and Race in the 19th and 20th Century British Empire. In Becoming Visible: Women in European History. R. Bridenthal et al., eds. Boston: Houghton Mifflin, 375-396.

Stuurman, Siep

1985 Verzuiling, Kapitalisme en Patriarchaat. Nijmegen:SUN.

Sutherland, Heather

1982 Ethnicity and Access in Colonial Macassar. In Papers of the Dutch-Indonesian Historical Conference. Leiden: Bureau of Indonesian Studies, 250-277.

Takaki, Ronald

1977 Iron Cages. Berkeley: University of California Press.

Taylor, Jean

1977 The World of Women in the Colonial Dutch Novel. Kabar Seberang 2, 26-41.

1983 The Social World of Batavia. Madison: University of Wisconsin Press.

Tiffany, Sharon and Kathleen Adams

1985 The Wild Woman: An Inquiry into the Anthropology of an Idea. Cambridge, MA: Schenkman Publishing Co.

Tirefort, A.

1979 'Le Bon Temps': La Communauté Francaise en Basse Cote d'Ivoire pendant l'Entre-Deux Guerres, 1920-1940. Troisème Cycle, Centre d'Etudes Africaines, Paris.

Travaux du Groupe d'Etudes Coloniales

1910 La Femme Blanche au Congo. Brussels: Misch \& Thron.

Van Doorn, Jacques

1983 A Divided Society: Segmentation and Mediation in Late-Colonial Indonesia. Rotterdam: CASPA.

1985 Indie als Koloniale Maatschappy. In De Nederlandse samenleving sinds 1815. Holthoon, F.L. van, ed. Assen: Maastricht.

Van Helten, J. and K. Williams

1983 'The Crying Need of South Africa': The Emigration of Single British Women in the Transvaal, 1901-1910. Journal of South African Studies 10:1, 11-38.

Van Heyningen, Elizabeth $B$.

1984 The Social Evil in the Cape Colony 1868-1902: Prostitution and the Contagious Disease Acts. Journal of Southern African Studies 10;2:170-197.

Van Marle, A.

1952 De group der Europeanen in Nederlands-Indie. Indonesie, 5:2, 77-121; 5:3, 314-341; 5:5, 481-507:

Van Onselen, Charles

1982 Studies in the Social and Economic History of the Witwatersrand 1886-1914. Vol. I. New York: Longman.

Veerde, A.G.

1931 Onderzoek naar den omvang der werkloosheid op Java, November 1930-Juni 1931). Koloniale Studien $242-273 ; 503-533$.

Vellut, Jean-Luc

1982 Materiaux pour une image du Blanc dans la société coloniale du Congo Belge. In Stéréotypes Nationaux et Préjuqés Raciaux aux XIXe et XXe Siècles. Jean Pirotte ed. Leuven: Editions Nauwelaerts.

Vere Allen, J. de

1970 Malayan Civil Service, 1874-1941: Colonial Bureaucracy Malayan Elite. Comparative Studies in Society and History. 12,149-178.

Wanderken, $P$.

1943 Zoo leven onze kinderen. In Zoo Leven Wij in Indonesia. Deventer: Van Hoever: 172-187. 
Wertheim, Willem

1959 Indonesian Society in Transition. The Hague: Van Hoeve.

Winckel, Ch. W. F.

1938 The Feasibility of White Settlements in the Tropics: a Medical Point of View. Comptes Rendus du Congrès International de Céographie Amsterdam. Leiden: Brill, 345-56.

Woodcock, George

1969 The British in the Far East. New York: Atheneum.

submitted 6 April 1989

accepted 6 July 1989

final version received 27 July 1989 